\title{
REVIEW LITERATUR \\ ANALISIS PENGARUH FAKTOR RISIKO TERHADAP KEJADIAN STUNTING PADA ANAK BALITA
}

\author{
Budi Kristanto
}

\begin{abstract}
Background: stunting is the result of non-fulfillment of nutrients as per the terms of nutrition in growth between the period of conception to age 24 months. Stunting reflects the accumulated growth retardation before and after birth. Failure of growth during childhood and often irreversible effect on adult life is short stature. The cause stunting very complex.

Objective: the aim of this literature review to analyze the effect of risk factors on the incidence of stunting in children under five.

Methods: the literature review conducted by Critical appraisal. The inclusion criteria include children with stunting, aged 0-59 months, have KMS, still have a father and a mother. While exclusion criteria specified are children who do not have KMS, children who have no parents. Data extracted from multiple sources and then synthesized into a review article from 6 different articles.

Results: factor nutritional status and body weight $\geq 2,500$ grams, socioeconomic for class C (poorest), aged 12-23 months, the duration of breastfeeding a child for 6-12 months and the mother's education with secondary and higher education have a significant influence on the incidence of stunting children ( $\rho$-value $=<0.001 ;<0.001 ;<0.001 ;<0.001$; $<0.002$ and $<0.008$ ). Nutritional status and body weight $\geq 2,500$ grams, socioeconomic for class $C$ (poorest) and the duration of breastfeeding a child for 6-12 months is a risk factor for children to experience stunting, while the mother's education at secondary and higher education is not a risk factor stunting of children ( $\mathrm{OR}=0.83$ and 0.73 ).

Conclusions: social and economic factors are dominant factors on the risk of children experiencing stunting $(\mathrm{OR}=4.8)$.
\end{abstract}

Keywords: stunting, toddler, risk factors

\section{PENDAHULUAN}

Pada usia di bawah 1 tahun balita belum memiliki aktivitas motorik yang berlebihan. Menginjak usia 2 th, motorik anak meningkat pesat. Pertumbuhan bayi cenderung ditandai dengan pertumbuhan cepat (growth spurt) yang dimulai pada usia 3 bulan hingga usia 2 tahun. Jika tidak diimbangi dengan asupan gizi, maka anak dapat mengalami stunting. Kejadian stunting kurang disadari kejadiannya oleh masyarakat terutama ibu dan keluarga balita (Rosha, 2012).

Stunting adalah hasil dari tidak terpenuhinya nutrisi sesuai syarat gizi pada pertumbuhan antara masa konsepsi sampai usia anak 24 bulan. Diketahui kejadian stunting mengidentifikasikan bahwa nutrisi tidak cukup untuk digunakan untuk pertumbuhan saja. Tetapi juga untuk fungsi tubuh kritis lainnya seperti otak atau system imun tubuh. Karena perkembangan kritis fisik dan mental terjadi diantara masa konsepsi sampai dengan 24 bulan pertama kehidupan, perkembangan selama fase ini menentukan potensi kehidupan individu dalam hal resiko terhadap kesakitan dan kematian, prestasi sekolah, kekuatan fisik, dan resiko penyakit kronis. Fase ini dikenal sebagai jendela 1000 hari (Bloem, dkk., 2013).

Konsekuensi dari mengalami dan tetap menjadi stunting adalah meningkatnya resiko angka 
kesakitan, kematian, keterlambatan dalam perkembangan motor dan mental serta penurunan kapasitas kerja (Gordon dan Halileh, 2013). Salah satu harapan MDGs adalah pencegahan tingkat kematian anak (Moore, 2011).

Penyebab stunting sangat kompleks. Namun, hal ini kemungkinan disebabkan oleh rendahnya kualitas intake diet yang terjadi secara terus menerus, begitu juga dengan kejadian infeksi yang berulang (Rah, dkk., 2010). Stunting bertanggung jawab atas kematian global pada anak sebesar $14-17 \%$ (Prendergast, dkk., 2014). Antara 171 juta dan 314 juta anak di dunia di bawah 5 tahun menderita stunting. $90 \%$ beban global ini terjadi di Afrika dan beberapa negara Asia (Fenske, Burns, Hothorn, dan Rehfuess, 2013). Di Indonesia, 37\% anak usia dibawah 5 tahun menderita stunting (Ramli, dkk., 2009).

Sedangkan berdasarkan data Riset Kesehatan Dasar kejadian stunting pada balita di Indonesia masih sangat tinggi, yaitu $36.8 \%$ pada tahun 2007 (Rosha, 2012). Berdasarkan data Riset Kesehatan Dasar (2007 dan 2010) kejadian stunting pada balita di Indonesia masih sangat tinggi, yaitu $36.8 \%$ (18.8\% sangat pendek dan $18.0 \%$ pendek) pada tahun 2007 dan $35.6 \%(18.5 \%$ sangat pendek dan $17.1 \%$ pendek) pada tahun 2010 atau lebih dari sepertiga balita di Indonesia (Renyoet, Hadju, dan Rochimiwati, 2013).

Beban global tentang kekurangan nutrisi pada anak usia kurang dari 5 tahun sekitar 300 juta anak. Perbaikkan status nutrisi pada anak adalah prioritas utama pada kesehatan anak. Untuk mengurangi beban tersebut sangat penting untuk melaksanakan kebijakkan yang tepat, intervensi dengan target penentu seperti pendidikan, status ekonomi dan pemberdayaan wanita (Ikeda dan Shibuya, 2013).

Nutrisi yang terpenuhi dengan optimal adalah jaminan pertumbuhan dan perkembangan dari anak serta sebagai dasar masa depan anak (Ramli, dkk., 2009). Sedangkan pertumbuhan optimal membutuhkan intake nutrisi dan energi yang adekuat, tanpa penyakit dan perawatan yang tepat (Monteiro, dkk., 2010).

\section{TUJUAN}

Menganalisis pengaruh faktor risiko terhadap kejadian stunting pada anak balita.

\section{DESAIN PENELITIAN}

Desain penelitian ini adalah literature review. Artikel-artikel yang dipilih adalah artikel correlation research yang menggunakan study cross sectional. Respondennya adalah anak dengan stunting usia 059 bulan. Artikel yang terkumpul dikelompokkan berdasarkan kriteria inklusi berikut : anak dengan stunting, berusia 0-59 bulan, memiliki KMS, masih memiliki ayah dan ibu. Sedangkan kriteria ekslusi yang ditetapkan adalah anak yang tidak memiliki KMS, anak yang sudah tidak memiliki orang tua. Hasil atau outcome yang diukur adalah analisis faktor-faktor yang berpengaruh terhadap kejadian stunting pada anak balita usia0-59 bulan.

Proses pelaksanaan systematic review dengan mengumpulkan artikel artikel menggunakan beberapa search engine guna menelusuri materi artikel terkait kejadian stunting pada anak. Engine yang digunakan diantaranya adalah Sciencedirect, MEDLINE-EBSCO, google search engine dengan kata kunci stunting, infant, children dan Indonesia. Sedangkan operator Boolean yang dipilih adalah "OR" guna memperluas area pencarian. 
Pemilihan judul artikel tidak menetapkan limit maupun filter termasuk batasan tahun karena penelitian mengenai stunting termasuk terbatas. Tahun artikel tertua yang didapat tahun 2007 dan terbaru tahun 2013. Format artikel full pdf, berbahasa Inggris pada hasil pencarian melalui EBSCO dan berbahasa Indonesia pada hasil pencarian google search dengan format kata kunci [stunting pada anak+artikel+pdf] serta merupakan artikel tidak berbayar.

Metode pengkajian kualitas study menggunakan aplikasi Critical Appraisal Skills Programme. Pelaksanaannya menggunakan CASP checklist untuk case control study dengan menjawab 11 pertanyaan screening questions. Proses selanjutnya adalah ekstraksi data dengan mengelompokkan data menurut variabel yang ingin dikaji. Setelah terkumpul langkah selanjutnya adalah sintesis data untuk dihubungkan guna mendapatkan korelasi faktor penyebab stunting dengan kejadian stunting. Faktor apakah yang sangat berperan.

\section{HASIL ANALISIS}

1. Pengaruh Panjang badan lahir terhadap kejadian stunting pada anak

Panjang badan lahir dapat dikaitkan dengan riwayat status gizi selama kehamilan. Anak dengan IUGR memiliki potensi untuk mengalami stunting. Dari 6 artikel yang ditelaah tidak ditemukan artikel yang membahas tentang hubungan panjang badan lahir dengan kejadian stunting pada anak. Sehingga tidak dapat dikaji pengaruh antara panjang badan lahir dengan kejadian stunting.

2. Pengaruh status gizi terhadap kejadian stunting pada anak Dari 6 artikel terkait, hanya ada 1 artikel yang membahas mengenai pengaruh status gizi anak dengan kejadian stunting. Data yang didapat adalah data dari Nigeria berdasarkan berat badan lahir, yaitu dengan berat badan lahir kurang dari 2.500 gram dan dengan berat badan lahir $\geq 2.500$ gram. Hasil uji statistik dengan menggunakan uji logistic regression menunjukkan bahwa nilai Odds Ratio (OR) untuk anak dengan berat badan lahir kurang dari 2.500 gramadalah $1.21(95 \% \mathrm{Cl}=1.10$ -1.33). Hal ini berarti bahwa status gizi dengan berat badan lahir kurang dari 2.500 gram $\geq$ 2.500 gram memiliki risiko mengalami stunting sebesar 1.2 kali. Selanjutnya, memiliki $\rho$ value $=<0.001$. Hal ini berarti bahwa faktor status gizi dengan berat badan lahir kurang dari 2.500 gram memiliki pengaruh secara bermakna terhadap kejadian stunting pada anak (Adekanmbi, Kayode dan Uthman, 2013).

3. Pengaruh umur anak terhadap kejadian stunting pada anak

Dari 6 artikel terkait, ada 2 artikel yang membahas mengenai pengaruh umur anak dengan kejadian stunting. Di Nigeria, hasil uji statistik dengan menggunakan uji logistic regression menunjukkan bahwa anak usia 12 - 23 bulan memiliki nilai Odds Ratio (OR) sebesar $2.24(95 \% \mathrm{Cl}=1.94-2.60)$. Selanjutnya anak usia $24-35$ bulan $(\mathrm{OR}=2.01,95 \% \mathrm{Cl}$ : $1.72-$ 2.34) dan memiliki $\rho$-value $=<$ 0.001 . Hal ini berarti bahwa umur anak 12 - 23 bulan memiliki risiko mengalami stunting sebanyak 2.24 kali sedangkan anak usia 24 - 35 bulan memiliki risiko mengalami stunting sebanyak 2.01 kali. Selanjutnya, $\rho$-value baik anak usia $12-23$ bulan maupun usia $24-35$ bulan adalah $<0.05$ Hal ini 
menunjukkan bahwa ada pengaruh secara bermakna antara usia dengan kejadian stunting pada anak (Adekanmbi, Kayode, dkk., 2013).

Di Maluku, hasil uji statistik dengan menggunakan uji logistic regression menunjukkan bahwa anak usia $0-23$ bulan memiliki nilai Odds Ratio (OR) 1.10(95\% $\mathrm{Cl}=1.07-1.14)$ sedangkan pada anak usia 0 - 59 bulan (OR $=1.11,95 \% \mathrm{Cl}: 1.08-1.14)$. Hal ini berarti bahwa anak $0-23$ bulan memiliki risiko mengalami stunting sebanyak 1.10 kali sedangkan anak usia 24 - 35 bulan memiliki risiko mengalami stunting sebanyak 1.11 kali. Selanjutnya, $\rho$-value baik anak usia $0-23$ bulan maupun usia 0 - 59 bulan adalah> 0.05. Hal ini menunjukkan bahwa tidak ada pengaruh antara usia dengan kejadian stunting pada anak (Ramli, dkk., 2009).

4. Pengaruh kecukupan ASI terhadap kejadian stunting pada anak

Dari 6 artikel terkait, ada 2 artikel yang membahas mengenai pengaruh kecukupan ASI dengan kejadian stunting. Di Nigeria, hasil uji statistik dengan menggunakan uji logistic regression menunjukkan bahwa anak usia 6-12 bulan memiliki nilai Odds Ratio (OR) sebesar $2.13(95 \% \mathrm{Cl}=1.83-2.48)$, usia $13-24$ bulan $(\mathrm{OR}=2.66 ; 95 \%$ $\mathrm{Cl}: 2.24-3.17)$ dan $(\mathrm{OR}=3.74$; $95 \%$ Cl: 2.90 - 4.83). Hal ini berarti bahwa lama menyusui anak 6-12 bulan memiliki risiko mengalami stunting sebanyak 2.13 kali, sedangkan pada anak usia $13-24$ bulan sebanyak 2.66 kali, dan usia $>24$ bulan sebanyak 3.74 kali. Selanjutnya, $\rho$-value baik pada anak $6-12$ bulan, $13-24$ bulan dan > 24 bulan adalah $<0.001$. Hal ini berarti bahwa ada pengaruh secara bermakna antara kecukupan ASI dengan kejadian stunting pada anak (Adekanmbi, Kayode, dkk., 2013).

Di Pilipina, hasil uji statistik dengan menggunakan uji ChiSquare menunjukkan $\rho$-value $=$ 0.09 . Hal ini berarti bahwa tidak ada pengaruh secara bermakna antara kecukupan ASI dengan kejadian stunting pada anak (Rohner, dkk., 2013).

5. Pengaruh status ekonomi terhadap kejadian stunting pada anak

Dari 6 artikel terkait, ada 3 artikel yang membahas mengenai pengaruh status ekonomi dengan kejadian stunting. Di Pilipina, hasil uji statistik dengan menggunakan uji logistic regression menunjukkan bahwa berdasarkan sosial ekonomi untuk kelas C (poorest) didapatkan nilai Odds Ratio (OR) sebesar $4.8(95 \% \mathrm{Cl}=2.4-9.4)$ dan $\rho$-value $=<0.001$. Hal ini berarti bahwa anak dengan sosial ekonomi kelas $\mathrm{C}$ memiliki risiko mengalami stunting sebesar 4.8 kali. Demikian halnya untuk sosial ekonomi untuk kelas D (poor) didapatkan nilai Odds Ratio (OR) sebesar $2,4(95 \% \mathrm{Cl}$ $=1.4-4.4)$ dan uji Chi-Square menunjukkan $\rho$-value $=0.001$. Hal ini berarti bahwa anak dengan sosial ekonomi kelas $D$ memiliki risiko mengalami stunting sebesar 2.4 kali. Secara statistik memiliki hubungan yang bermakna $(\rho$-value $<0.05)$ (Rohner, dkk., 2013).

Di Nigeria, hasil uji statistik dengan menggunakan uji logistic regression menunjukkan bahwa ibu yang bekerja secara serabutan memiliki nilai Odds Ratio (OR) sebesar $1.01(95 \% \mathrm{Cl}$ $=0.93-1.11$ ) dan pekerja kantoran memiliki OR $=1.00$ (95\% Cl: 0.90 - 1.08). Hal ini berarti bahwa ibu yang bekerja 
secara serabutan memiliki anak dengan risiko mengalami stunting sebanyak 1.01 kali, sedangkan pada ibu pekerja kantoran sebanyak 1.00 kali. Selanjutnya, $\rho$-value baik pada ibu yang bekerja secara serabutan dan ibu pekerja kantoran adalah 0.720 dan 0.768. Hal ini berarti bahwa tidak ada pengaruh secara bermakna antara pekerjaan ibu terhadap kejadian stunting pada anak (Adekanmbi, Kayode, dkk., 2013).

Di Maluku, berdasarkan pekerjaan ayah adalah tertinggi pada ayah yang tidak bekerja, yaitu hasil uji statistik dengan menggunakan uji logistic regression menunjukkan bahwa anak usia $0-23$ bulan memiliki nilai Odds Ratio (OR) 1.45 (95\% $\mathrm{Cl}=0.63-3.34)$ sedangkan pada anak usia 0 - 59 bulan (OR $=1.65,95 \% \mathrm{Cl}: 0.92-2.94)$. Hal ini berarti bahwa ayah yang tidak bekerja dengan anak usia $0-23$ bulan memiliki risiko mengalami stunting sebanyak 1.45 kali sedangkan dengan anak usia 24-35 bulan memiliki risiko mengalami stunting sebanyak 1.65 kali. Selanjutnya, $\rho$-value baik pada ayah yang tidak bekerja dengan anak usia $0-23$ bulan maupun usia $0-59$ bulan adalah > 0.05. Hal ini menunjukkan bahwa tidak ada pengaruh antara status pekerjaan ayah dengan kejadian stunting pada anak (Ramli, dkk., 2009b).

Sedangkan pada ibu, tertinggi pada ibu yang berprofesi sebagai nelayan, yaitu hasil uji statistik dengan menggunakan uji logistic regression menunjukkan bahwa anak usia $0-23$ bulan memiliki nilai Odds Ratio (OR) 1.33 (95\% $\mathrm{Cl}=0.62-2.88)$ sedangkan pada anak usia 0 - 59 bulan (OR $=1.31,95 \% \mathrm{Cl}: 0.78-2.22)$. Hal ini berarti bahwa pekerjaan ibu sebagai nelayan dengan anak
0-23 bulan memiliki risiko mengalami stunting sebanyak 1.33 kali, sedangkan anak usia 24-35 bulan memiliki risiko mengalami stunting sebanyak 1.31 kali. Selanjutnya, $\rho$-value baik pada pekerjaan ibu sebagai nelayan dengan anak usia 0-23 bulan maupun usia anak 0-59 bulan adalah > 0.05. Hal ini menunjukkan bahwa tidak ada pengaruh antara status pekerjaan ibu dengan kejadian stunting pada anak (Ramli, dkk., 2009b).

6. Pengaruh tingkat pendidikan orang tua terhadap kejadian stunting pada anak

Dari 6 artikel terkait, ada 3 artikel yang membahas mengenai pengaruh tingkat pendidikan orang tua terhadap kejadian stunting pada anak. Di Pilipina, hasil uji statistik dengan menggunakan uji Chi-Square menunjukkan bahwa $\rho$-value $=<$ 0.001 . Hal ini berarti bahwa ada pengaruh antara status pendidikan ibu terhadap kejadian stunting pada anak (Rohner, dkk., 2013).

Di Nigeria, hasil uji statistik menunjukkan bahwa untuk pendidikan menengah memiliki $\rho$ value $=0.002(\mathrm{OR}=0.83 ; \mathrm{Cl}$ $95 \%=0.74-0.94)$ dan pendidikan tinggi memiliki $\rho$-value $=0.008$ (OR= $0.73 ; \mathrm{Cl} 95 \%=0.58-0.92)$. Hal ini berarti bahwa ibu dengan pendidikan menengah dan tinggi memiliki pengaruh secara bermakna terhadap kejadian stunting, namun bukan merupakan faktor risiko kejadian stunting terhadap anak (Adekanmbi, Kayode, dkk., 2013).

Di Maluku, hasil uji statistik menunjukkan berdasarkan pendidikan ayah, tertinggi pada SMP, yaitu anak dengan usia 0-23 bulan memiliki OR sebesar 0.84 dengan $\mathrm{Cl} 95 \%=0.59-1.21$, sedangkan untuk anaku sia 0-59 
bulan memiliki OR sebesar 0.90 dengan $\mathrm{Cl} 95 \%=0.71-1.14$. Sedangkan berdasarkan pendidikan ibu juga tertinggi pada SMP, yaitu anak usia 0-23 bulan memiliki OR sebesar 0.95 dengan $\mathrm{Cl} 95 \%=0.69-1.31$, sedangkan untuk anak usia 0-59 bulan memiliki OR sebesar 0.85 dengan $\mathrm{Cl} 95 \%=0.66-1.09$. Hal ini berarti bahwa baik pendidikan ayah maupun ibu tidak memiliki pengaruh sebagai faktor risiko terjadinya stunting pada anak, namun sebagai protektif (Ramli, dkk., 2009b).

7. Pengaruh tinggi badan orang tua terhadap kejadian stunting pada anak

Dari 6 artikel, hanya 1 artikel yang membahas mengenai tinggi badan ibu. Penelitian di Bangladesh menyebutkan tinggi badan ibu $<150 \mathrm{~cm}$ sebanyak 75 . 951 dengan kejadian stunting sebanyak 64. 393 pada sampel sebesar 165. 111 anak. Namun pemaparan ini belum bisa untuk menunjukkan adanya pengaruh antara tinggi badan orang tua dan kejadian stunting pada anak. Oleh karena artikel yang ada hanya mengukur prevalensinya saja.

\section{PEMBAHASAN}

1. Pengaruh Status gizi terhadap kejadian stunting pada anak

Menurut Adekanmbi (2013) di Nigeria dari 28.647 terdapat 7.322 anak yang mengalami stunting sedangkan 21.325 tidak mengalami stunting. Dari 7.322 anak yang mengalami stunting terbanyak pada usia 12-23 bulan, yaitu 1.819 anak, selanjutnya usia 36-47 bulan, yaitu 1.631, usia 24-35 bulan, yaitu 1.584, usia 48-59 bulan, yaitu 1.468 anak dan paling sedikit usia 0-11 bulan, yaitu 820 anak. Hal ini menunjukkan bahwa pada usia anak 12-23 bulan sangat rentan untuk mengalami penurunan berat badan. Selain itu, berdasarkan berat badan lahir dari 7.322 anak yang mengalami stunting terdapat 1.210 anak lahir dengan berat badan kurang dari 2.500 gram dan 6.000 anak lahir dengan berat badan $\geq 2.500$ gram (Adekanmbi, dkk., 2013).

Usia 12-23 tahun merupakan usia anak mengalami perkembangan yang pesat dalam kemampuan kognitif dan motorik. Diperlukan status gizi yang optimal untuk mendukung perkembangan ini. Status gizi rendah disebabkan oleh penyebab langsung dan tidak langsung. Penyebab langsung salah satunya adalah konsumsi makanan yang kurang. Sedangkan penyebab tidak langsung yang dominan meliputi tingkat ekonomi yang kurang, pendidikan umum dan pendidikan gizi yang kurang. Gizi yang cukup diperlukan setiap orang untuk mencapai pertumbuhan yang optimal. Status gizi optimal terjadi bila tubuh memperoleh cukup zat-zat gizi yang digunakan secara efisien (Isdaryanti, 2007).

Kurang gizi akan menghambat pertumbuhan otak mereka secara optimal, yang pada akhirnya, akan membatasi kemampuan mereka untuk bertahan hidup (Kharas, 2013). Kekurangan gizi pada bayi pertama kali ditunjukkan dengan berat lahir yang kurang dari 2.500 gram. Sebagai konsekuensinya organorgan tubuh seperti kepala, tangan dan kaki lebih kecil dari ukuran normal disamping biasanya sang bayi lebih rentan terhadap penyakit infeksi (Kombong dan Yuristianti, 2000).

2. Pengaruh umur terhadap kejadian stunting pada anak Stunting sering terjadi pada anak usia 1 tahun ke atas, dimana aktifitas anak bertambah. 
Semakin bertambah usia maka semakin bertambah kebutuhan gizi dan aktifitas. Jika tidak diimbangi dengan asupan nutrisi yang adekuat, maka anak dapat terancam kekurangan gizi bahkan stunting. Dari 6 artikel, 5 diantaranya mengkaji pengaruh antara usia dan kejadian stunting. Dari 5 artikel, 2 artikel meneliti pengaruh usia/umur anak terhadap kejadian stunting adalah umur berpengaruh terhadap kejadian stunting di Nigeria. Kemudian umur anak 12-23 bulan memiliki risiko mengalami stunting sebanyak 2.24 kali sedangkan anak usia 24-35 bulan memiliki risiko mengalami stunting sebanyak 2.01 kali (Adekanmbi, dkk., 2013). Sedangkan di Maluku, hasil analisis statistik menunjukkan bahwa tidak ada pengaruh antara usia dengan kejadian stunting pada anak (Ramli, dkk., 2009b).

Kejadian di Maluku bertentangan dengan penyataan Kusuma (2013) namun selaras dengan kejadian di Nigeria, yaitu stunting pada masa balita perlu mendapat perhatian khusus termasuk pada anak usia 2-3 tahun. Proses pertumbuhan pada usia 2-3 tahun cenderung mengalami perlambatan sehingga peluang untuk terjadinya kejar tumbuh lebih rendah dibanding usia 0-2 tahun.

3. Pengaruh tingkat pendidikan orang tua terhadap kejadian stunting pada anak

Pendidikan adalah faktor lain yang sangat berperan dalam menentukan masa depan anak termasuk dalam pemenuhan gizi. Orang tua yang memiliki pendidikan baik akan mengasuh anak-anak mereka dengan baik dan sehat pula. Dari ke 6 artikel, semua artikel tersebut membahas mengenai keutamaan pendidikan dalam kejadian stunting pada anak. Namun, hanya ada 3 artikel yang meneliti pengaruh tingkat pendidikan orang tua terhadap kejadian stunting pada anak. Ramli dalam penelitiannya memisahkan antara pendidikan ayah, ibu dan orangtua.

Di Philipina dan Nigeria menjelaskan bahwa status pendidikan ibu berpengaruh terhadap kejadian stunting pada anak. Di Philipina semakin tinggi pendidikan ibu, semakin rendah kejadian stunting (Rohner, dkk., 2013). Sedangkan di Nigeria, pendidikan ibu memiliki pengaruh, tetapi bukan faktor resiko kejadian stunting pada anak (Adekanmbi, Kayode, dkk., 2013). Penelitian ketiga yang menunjukkan pengaruh adalah penelitian di Maluku. Hasil penelitian menunjukkan bahwa pendidikan ibu dan ayah bukanlah faktor resiko melainkan sebagai protektif terhadap kejadian stunting (Ramli, dkk., 2009a).

Menurut Sulastri tingkat pendidikan akan mempengaruhi konsumsi pangan melalui cara pemilihan bahan pangan. Orang yang berpendidikan lebih tinggi cenderung untuk memilih bahan makanan yang lebih baik dalam kualitas dan kuantitas hidangan dibandingkan mereka yang berpendidikan rendah atau sedang. Makin tinggi tingkat pendidikan makin baik status gizi anaknya (Sulastri, 2012).

4. Pengaruh kecukupan ASI terhadap kejadian stunting pada anak

Pemberian ASI utamanya ASI Ekslusif adalah salah satu sumber makanan bergizi bagi anak. Kandungan gizinya yang sempurna dan antibodi melindungi anak dari penyakit terutama penyakit infeksi 
berulang. Selain itu, juga dapat menghindarkan anak mengalami stunted. Oleh karena selain kekurang gizi kronis, stunting juga dapat disebabkan oleh kejadian penyakit infeksi berulang pada anak.

Dua artikel yang membahas mengenai pengaruh kecukupan ASI dengan kejadian stunting aalah di Philipina dan Nigeria. Di Pilipina, hasil penelitian menunjukkan tidak ada pengaruh secara bermakna antara kecukupan ASI dengan kejadian stunting pada anak (Rohner, dkk., 2013). Hasil penelitian di Nigeria menunjukkan bahwa ada pengaruh secara bermakna antara kecukupan ASI dengan kejadian stunting pada anak. Lama menyusui anak $6-12$ bulan memiliki risiko mengalami stunting sebanyak 2.13 kali, sedangkan kejadian pada anak usia 13-24 bulan sebanyak 2.66 kali, dan usia $>24$ bulan sebanyak 3.74 kali. Pemberian ASI Eksklusif dari 7.322 anak yang mengalami stunting terdapat 357 anak yang mendapatkan ASI Eksklusif < 6 bulan dan 1.217 anak diberikan ASI sampai usia 6-12 bulan (Adekanmbi, Kayode, et al., 2013). Selain itu, di India dari 12.176 responden, terdapat prevalensi balita yang mendapatkan ASI esklusif dengan stunting ( $z$-score $\leq-2)$ sebanyak 4.481 orang. Sedangkan anak dengan stunting sangat pendek (z-score $\leq 3$ ) sebanyak 2.082 orang. Hal ini berarti bahwa ada kecenderungan anak yang mendapatkan ASI ekslusif kemungkinan menderita stunting lebih kecil dibandingkan anak yang tidak diberi ASI ekslusif.

Pemberian ASI yang tepat dapat mencegah pertumbuhan gangguan (stunting).
Pemberan ASI dan MP-ASI yang tepat cegah gangguan pertumbuhan (pendek/stunting). Stunting pada 12 bulan pertama kehidupan balita dapat diturunkan dengan pemberian ASI dan MP-ASI yang tepat. Oleh karena, pemberian ASI secara eksklusif dapat menjamin kebutuhan gizi bayi terpenuhi, apalagi ASI merupakan makan terbaik. Selain itu, ASI juga merupakan makanan terbaik bagi anak sampai usia 2 tahun (Ahmad, 2010).

ASI merupakan satu-satunya makanan terbaik bagi bayi sampai berumur 6 bulan karena mempunyai komposisi gizi yang paling lengkap dan ideal untuk pertumbuhan dan perkembangan bayi yang dapat memenuhi kebutuhan gizi bayi selama 6 bulan pertama. Rekomendasi pemberian ASI saja yang dikenal dengan ASI eksklusif sampai 6 bulan didasarkan pada bukti ilmiah tercukupinya kebutuhan bayi dan lebih baiknya pertumbuhan bayi yang mendapat ASI eksklusif serta menurunnya morbiditas bayi (Kramer, 2002).

5. Pengaruh status ekonomi terhadap kejadian stunting pada anak

Kemampuan ekonomi sangat berperan dalam pemenuhan kebutuhan gizi anak. Semakin tinggi status ekonomi sebuah keluarga maka semakin beragam dan berbobot nilai gizi yang diberikan untuk anak. Sebaliknya rendahnya status ekonomi memaksa keluarga untuk memberikan asupan gizi yang tidak adekuat untuk anak.

Dari 6 artikel terkait, ada 3 artikel yang membahas mengenai pengaruh status ekonomi dengan kejadian stunting. Di Pilipina, anak dengan sosial ekonomi kelas C memiliki risiko 
mengalami stunting sebesar 4.8 kali. Demikian halnya untuk sosial ekonomi untuk kelas D (poor), anak dengan sosial ekonomi kelas $D$ memiliki risiko mengalami stunting sebesar 2.4 kali. Secara statistik memiliki hubungan yang bermakna (Rohner, dkk., 2013).

Di Nigeria, tidak ada pengaruh secara bermakna antara pekerjaan ibu terhadap kejadian stunting pada anak (Adekanmbi, Kayode, dkk., 2013).

Di Maluku, hasil penelitian menunjukkan tidak ada pengaruh antara status pekerjaan ayah dengan kejadian stunting pada anak. Sedangkan pada ibu, tidak ada pengaruh antara status pekerjaan ibu dengan kejadian stunting pada anak (Ramli, dkk., 2009b).

Anak pada keluarga dengan tingkat ekonomi rendah lebih berisiko mengalami stunting karena kemampuan pemenuhan gizi yang rendah, meningkatkan risiko terjadinya malnutrisi. Pendapatan perkapita juga merupakan faktor yang turut menentukan status gizi balita. Kemiskinan yang berlangsung dalam waktu lama dapat mengakibatkan rumah tangga tidak mampu untuk memenuhi kebutuhan pangan dengan kualitas dan kuantitas yang baik. Penurunan kualitas konsumsi pangan rumah tangga yang dicirikan oleh keterbatasan membeli pangan sumber protein, vitamin dan mineral akan berakibat pada kekurangan gizi, baik zat gizi makro maupun mikro (Krebs, dkk., 2011).

6. Pengaruh Tinggi badan orang tua terhadap kejadian stunting pada anak

Hasil penelitian di Bangladesh menunjukkan bahwa dari 165.111 anak terdapat 82.556 orang yang mengalami stunting (-
2.01 \pm 0.003$)$. Sekitar 75.951 orang ibu diantaranya yang memiliki tinggi badan kurang dari $150 \mathrm{~cm}$ (<150 cm) (Rah, dkk., 2010). Hal ini berarti bahwa adanya kecenderungan bahwa anak yang pendek memiliki orangtua yang pendek pula.

Tinggi badan orang tua sangat mempengaruhi faktor hereditas atau keturunan pada anak. Postur anak yang pendek bukan hanya karena stunting tetapi bisa juga dikarenakan oleh faktor keturunan. Tinggi badan merupakan salah satu bentuk dari ekspresi genetik, dan merupakanfaktor yang diturunkan kepada anak serta berkaitan dengan kejadian stunting. Anak dengan orang tua yang pendek, baik salah satu maupun keduanya, lebih berisiko untuk tumbuh pendek dibanding anak dengan orang tua yang tinggi badannya normal. Orang tua yang pendek karena gen dalam kromosom yang membawa sifat pendek kemungkinan besar akan menurunkan sifat pendek tersebut kepada anaknya. Tetapi bila sifat pendek orang tua disebabkan karena masalah nutrisi maupun patologis, maka sifat pendek tersebut tidak akan diturunkan kepada anaknya (Kusuma, 2013).

\section{KESIMPULAN}

Berdasarkan hasil dan pembahasan dalam review literatur ini, maka dapat dibuat simpulan bahwa faktor status gizi dengan berat badan lahir $<2.500$ gram memiliki pengaruh secara bermakna terhadap kejadian stunting pada anak dan memiliki risiko mengalami stunting sebesar 1.2 kali. Faktor lama menyusui anak selama 6-12 bulan memiliki pengaruh secara bermakna terhadap kejadian stunting pada anak dan memiliki risiko mengalami stunting sebanyak 2.13 kali. Faktor 
usia anak dengan usia 12-23 bulan memiliki pengaruh secara bermakna terhadap kejadian stunting pada anak dan memiliki risiko mengalami stunting sebanyak 2.24 kali.

Faktor sosial ekonomi untuk kelas C (poorest) memiliki pengaruh secara bermakna terhadap kejadian stunting pada anak dan memiliki risiko mengalami stunting sebanyak 4.8 kali. Faktor pendidikan ibu dengan pendidikan menengah dan tinggi memiliki pengaruh secara bermakna terhadap kejadian stunting pada anak, namun bukan merupakan faktor risiko kejadian stunting terhadap anak (OR $=0.83$ dan 0.73). Faktor sosial ekonomi merupakan faktor dominan terhadap risiko anak mengalami stunting.

\section{SARAN}

Pada penelitian selanjutnya diperlukan analisis lebih dalam mengenai pengaruh berat badan lahir pada anak, sosial ekonomi dan pengaruh tinggi badan orang tua. Sedangkan pada masyarakat, perlu ditingkatkan pemberian informasi berupa penyuluhan kepada orang tua balita mengenai faktor risiko kejadian stunting apada anak termasuk pentingnya mengkonsumsi bahan makanan sumber zat energi dan protein sehingga dapat mencegah stunting pada anak balita.

\section{DAFTAR PUSTAKA}

Adekanmbi, V. T., Kayode, G. A., dan Uthman, O. A. (2013). Original Article Individual and contextual factors associated with childhood stunting in Nigeria: a multilevel analysis, 244-259. doi:10.1111/j.17408709.2011.00361.x

Adekanmbi, V. T., Uthman, O. A., dan Mudasiru, O. M. (2013). Exploring variations in childhood stunting in Nigeria using league table, control chart and spatial analysis.
Bloem, M. W., Pee, S. De, Hop, L. T., Khan, N. C., Laillou, A., Moench-pfanner, R., Asia, S. (2013). Key strategies to further reduce stunting in Southeast Asia : Lessons from the ASEAN countries workshop, 34(2), 817.

Bunga Ch Rosha1, H. dan Y. F. B. (2012). Analisis Determinan Stunting Anak 0-23 Bulan Pada Daerah Miskin Di Jawa Tengah Dan Jawa Timur (Determinant Analysis Of Stunting Children Aged 0-23 Months In Poor Areas In Central And East Java), 35(1), 34-41. Retrieved from

http://webcache.googleusercon tent.com/search?q=cache:Swh _Cemp1dYJ:ejournal.litbang.de pkes.go.id/index.php/pgm/articl e/download/3081/3049+dancd= 4danhl=iddanct $=$ lnkdanclient $=f$ irefox-beta

Chang, S. M., Walker, S. P., dan Christine, S. G. (2010). Early childhood stunting and later fine motor abilities. doi:10.1111/j.14698749.2010.03640.x

Fenske, N., Burns, J., Hothorn, T., dan Rehfuess, E. A. (2013). Understanding Child Stunting in India: A Comprehensive Analysis of Socio-Economic , Nutritional and Environmental Determinants Using Additive Quantile Regression, 8(11). doi:10.1371/journal.pone.00786 92

Gordon, N. H., dan Halileh, S. (2013). An analysis of cross sectional survey data of stunting among Palestinian children less than five years of age. Maternal and Child Health Journal, 17(7), 1288-96. doi:10.1007/s10995-012-11264 
Ikeda, N., dan Shibuya, K. (2013). Determinants of reduced child stunting in Cambodia: analysis of pooled data from three Demographic and Health Surveys, (February), 341-349.

Monteiro, C. A., Aquino, H. D., Conde, L., Konno, S., dan Lucia, A. (2010). Narrowing socioeconomic inequality in child stunting: the Brazilian experience , 1974 - 2007, (June 2009), 305-311. doi:10.2471/BLT.09.069195

Moore, D. (2011). Influence of Maternal Education on Child Immunization and Stunting in Kenya, 1389-1399. doi:10.1007/s10995-010-0670$z$

Onis, M. De, Dewey, K. G., Borghi, E., Onyango, A. W., Blössner, M., Daelmans, B., Branca, F. (2013). Orginal Article The World Health Organization' $s$ global target for reducing childhood stunting by 2025 : rationale and proposed actions, 9 , 6-26. doi: $10.1111 / \mathrm{mcn} .12075$

Prendergast, A. J., Rukobo, S., Chasekwa, B., Mutasa, K., Ntozini, R., Mbuya, M. N. N., Humphrey, J. H. (2014). Stunting Is Characterized by Chronic Inflammation in Zimbabwean Infants, 9(2). doi:10.1371/journal.pone.00869 28

Rah, J. H., Akhter, N., Semba, R. D., Pee, S. De, Bloem, M. W., Campbell, A. A., Kraemer, K. (2010). Low dietary diversity is a predictor of child stunting in rural Bangladesh, 1393-1398. doi:10.1038/ejcn.2010.171

Ramli, Agho, K. E., Inder, K. J., Bowe, S. J., Jacobs, J., dan Dibley, M. J. (2009a). Prevalence and risk factors for stunting and severe stunting among under-fives in North Maluku province of Indonesia.
BMC Pediatrics, 9, 64. doi:10.1186/1471-2431-9-64

Ramli, Agho, K. E., Inder, K. J., Bowe, S. J., Jacobs, J., dan Dibley, M. J. (2009b). Prevalence and risk factors for stunting and severe stunting among under-fives in North Maluku province of Indonesia. BMC Pediatrics, 9, 64. doi:10.1186/1471-2431-9-64

Renyoet, B. S., Hadju, V., dan Rochimiwati, S. N. (2013). Hubungan Pola Asuh Dengan Kejadian Stunting Anak Usia 623 Bulan Di Wilayah Pesisir Kecamatan Tallo Kota Makassar Connection Between Parenting And Stunting Case On Children Age 6-23 Months In Coastal Region District Tallo Makassar Wilayah pesisir merupa, 1-13.

Rohner, F., Woodruff, B. A., Aaron, G. J., Yakes, E. A., Lebanan, M. A. O., Rayco-solon, P., dan Saniel, O. P. (2013). Infant and young child feeding practices in urban Philippines and their associations with stunting, anemia, and deficiencies of iron and vitamin A, 34(2), 17-35.

Semba, R. D., Moench-pfanner, R., Sun, K., Pee, S. De, Akhter, N., Rah, J. H., Kraemer, K. (2012). Consumption of micronutrientfortified milk and noodles is associated with lower risk of stunting in preschool-aged children in Indonesia, 32(4), 347-354.

Young, J. M., dan Solomon, M. J. (2009). How to critically appraise an article. Nature Clinical Practice.

Gastroenterology dan Hepatology, 6(2), 82-91. doi:10.1038/ncpgasthep1331

${ }^{1}$ Mahasiswa Magister Keperawatan Universitas Diponegoro Semarang 